Federal Reserve Bank of Dallas

Globalization and Monetary Policy Institute

Working Paper No. 100

http://www.dallasfed.org/assets/documents/institute/wpapers/2011/0100.pdf

\title{
Thousands of Models, One Story: Current Account Imbalances in the Global Economy*
}

\author{
Michele Ca' Zorzi \\ European Central Bank \\ Alexander Chudik \\ Federal Reserve Bank of Dallas \\ Alistair Dieppe \\ European Central Bank
}

December 2011

\begin{abstract}
The global financial crisis has led to a revival of the empirical literature on current account imbalances. This paper contributes to that literature by investigating the importance of evaluating model and parameter uncertainty prior to reaching any firm conclusion. We explore three alternative econometric strategies: examining all models, selecting a few, and combining them all. Out of thousands (or indeed millions) of models a story emerges. The chance that current accounts were aligned with fundamentals prior to the financial crisis appears to be minimal.
\end{abstract}

JEL codes: C11, C33, F32, F34, F41, O52

\footnotetext{
* Michele Ca’ Zorzi, European Central Bank, Monetary Policy Research Division, Kaiserstrasse 29, 60311 Frankfurt am Main, Germany. +49-69-1344-6563. michele.cazorzi@ecb.int. Alexander Chudik, Federal Reserve Bank of Dallas, 2200 N. Pearl Street, Dallas, TX 75201. 214-922-5769. Alexander.Chudik@dal.frb.org. Alistair Dieppe, European Central Bank, Monetary Policy Research Division, Kaiserstrasse 29, 60311 Frankfurt am Main, Germany. +49-69-1344-0. alistair.dieppe@ecb.int. We have benefited from valuable comments by Gianni Amisano, Matthieu Bussiere, Roberto De Santis, Michael Rubaszek, Frank Smets, Martin Wagner, and participants at a seminar at the European Central Bank. The views in this paper are those of the authors and do not necessarily reflect the views of the European Central Bank, the Federal Reserve Bank of Dallas or the Federal Reserve System.
} 


\section{Introduction}

There is a burgeoning debate on the relationship between current account imbalances and the global financial meltdown (Obstfeld and Rogoff, 2009, ECB, 2010, Chinn, 2011). Even before the financial crisis in 2008, some leading economists such as Obstfeld and Rogoff (2005), Eichengreen (2006), Frankel (2006) Krugman, (2007) and Williamson (2007) warned about the risks from global imbalances; they felt that the trigger might be a sizeable devaluation of the dollar. In the event, as underlined by Blanchard and Milesi-Ferretti (2009) and Obstfeld and Rogoff (2009), financial instability spread from the United States to the rest of the world mostly through financial interlinkages among highly leveraged institutions, as increased defaults in the US subprime market undermined securitized products. The freezing of the interbank market and the failure of systemically large institutions caused an unprecedented loss of confidence, which partially explained the subsequent collapse in global output and trade. The impact on the balance sheets of banks, corporations and the public sector weakened confidence still further, leading to a vicious circle that is entirely typical of financial crises but this time affected the core of the global financial system (Krugman, 2009).

Given this background, the renewed interest in current account imbalances is hardly surprising. The standard starting point in analyzing current accounts is the intertemporal approach which originated with Sachs (1981), and was later extended by Obstfeld and Rogoff (1994). Empirical studies on the intertemporal approach to the current account have been carried out by Sheffrin and Woo (1990), Otto (1992), Milbourne and Otto (1992), Otto and Voss (1995), Bergin (2006) and many others. Typically though, the simple intertemporal current account models have a poor empirical fit. Partly to address this issue, the basic intertemporal model has been extended in many directions. Several papers show the importance of introducing additional factors that could affect consumption / savings decisions: Bussière et al. (2006) extend the intertemporal model to include the role of fiscal policy; Galí et al. (2007) assume a fraction of households cannot optimize intertemporally, for example if they have no access to capital markets. Some researchers consider the impact of changing international conditions, assuming variable interest rates and exchanges rates (Bergin and Sheffrin, 2000), while others allow for endogenous investment (Glick and Rogoff 1995). In the context of common currency areas, Ca' Zorzi and Rubaszek (2008) argue that a sim-

ple intertemporal model, which includes net foreign assets, financing costs and expectations of economic convergence, helps explain the configuration of current account developments in the euro area before the financial turmoil. Finally, demographic factors could also be included in structural models, for example in an overlapping generations framework.

It is clear that the various structural models could potentially produce very different 
predictions on the relevant current account determinants, and there is a growing empirical literature that includes many of the drivers of current account positions suggested from different theoretical approaches; examples include Chinn and Prasad (2003), IMF (2006) and Rahman (2008). The robustness of the derived results is typically addressed by considering the homogeneity of the elasticities across different groupings of countries or by employing different estimation techniques.

The literature on current account imbalances has however largely ignored an important source of uncertainty. The set of plausible fundamentals determining the current account allows for thousands, or millions, of possible model combinations. It appears arbitrary to choose only one model unless there is a transparent selection procedure. The main contribution of this paper is to investigate the importance of model and parameter uncertainty before reaching any firm conclusions on the current account constellation which prevailed before the financial crisis. We look for clear cut conclusions by following different routes corresponding to three plausible econometric strategies. The first route consists in examining all models and checking if common features can be identified across all of them. The second route aims at choosing the best model, using a transparent selection procedure based on both economic and statistical criteria. The third and final route applies Bayesian techniques developed by Sala-i-Martin et al. (2004) to assess the probability of each model and also employs model combination techniques. The analysis is then taken a step further by calculating the probability of the current account position of any given country being misaligned. All three approaches allow us to assess whether there is evidence of imbalances in major economies, such as the US, the United Kingdom, China and Japan. ${ }^{1}$ Out of thousands or indeed millions of models, one consistent story emerges: the chance that current accounts were aligned with fundamentals prior to the financial crisis appears to be, according to this approach, minimal.

\section{Potential Determinants of Current Accounts}

Before going on to explain our estimation approach, we will first identify the main mediumterm determinants of current account deficits. Our objective is to provide an empirical, although not entirely atheoretical, characterization of current account determinants. Indeed, we use a variety of theoretical models to drive our estimation strategy and to provide guidance on the expected sign of the coefficients. In particular, we build upon the work of Debelle and Faruqee (1996), Calderon et al. (2002), Chinn and Prasad (2003), Doisy and Hervé (2003), Bussière et al. (2006), Zanghieri (2004), Gruber and Kamin (2005), Hermann and Jochem (2005), Aristovnik (2006), IMF (2006), De Santis and Lührmann (2008), and Rahman (2008).

\footnotetext{
${ }^{1}$ For an out of sample analysis of central and eastern European countries, see Ca' Zorzi et al. (2011).
} 
We start by outlining the main determinants of medium-term current account variation as identified by the above literature and the suggested theoretical priors for the expected signs. Later we also evaluate the impact of extending the set of plausible fundamentals even further.

The following variables are not constructed relative to foreign trading partners, because this is implicit in their definition.

- 'Initial' net foreign assets (NFA), as a share of GDP. Economies characterized by high levels of indebtedness (i.e. negative NFA) are expected eventually to improve their current account position to preserve long-term solvency, suggesting a negative association. On the other hand, highly indebted countries typically record negative income flows, which weigh negatively on the current account. The sign is ambiguous.

- Oil balance. There is a positive co-movement between the oil balance position of a country and its current account. In the literature this variable is used to proxy the sensitivity of a country to changes in oil prices.

In contrast, the following determinants are constructed as deviations from the weighted averages of foreign trading partners:

- Investment as a share of GDP. Current investment should lead to productivity gains in the future, and hence higher expected wealth, giving rise to an intertemporal adjustment which results in a current account deficit (Glick and Rogoff, 1995). Furthermore, an increase in a demand variable, such as investment, is associated with a worsening of the foreign trade balance. A negative sign is expected.

- Real GDP growth. The higher real GDP growth, the more likely workers are to project higher future income and to respond by increasing consumption. Consequently, a negative sign is expected.

- Fiscal balance. A variety of models (excluding those based on Ricardian equivalence) predict a positive relationship between government budget balances and current accounts over the medium term. For example, overlapping generations models suggest that government budget deficits tend to induce current account deficits by redistributing income from future to present generations (Obstfeld and Rogoff, 1994 and Chinn, 2005). Bussière et al. (2006) also found there was a connection between fiscal deficits and the current account (in line with the "twin deficits" idea). A positive coefficient is therefore expected.

- Relative income. Low-income countries are expected to have larger current account deficits as part of the catching-up process. Hence a positive coefficient is expected. Our measure is real GDP per capita in terms of purchasing power parity (PPP). 
- Demographic variables. A country with a relatively high share of economic dependents in the population is expected to have a lower level of national savings and hence a lower current account balance (IMF, 2006). As this depends on the proportion of the dependent population that is young or old, we include the following three variables:

- An old-age dependency ratio constructed as the ratio of people older than 65 years to the population aged between 14 and 65 .

- A youth dependency ratio constructed as the ratio of young people (under 14) to the population aged between 14 and 65 .

\section{- Population growth.}

Negative signs are expected for these variables.

- Civil liberties. Legal rights, functioning markets and efficient institutions should all ease access to international capital markets (De Santis and Lührmann, 2008). This is measured using an index from 1 (maximum degree of liberty) to 7 (minimum degree of liberty). A positive sign is expected.

- Trade integration is measured as the degree of openness relative to GDP. Openness is also commonly used in the literature as a proxy for barriers to trade (or even trade costs). The sign of the coefficient is ambiguous.

- Financial integration is defined as the sum of foreign assets and liabilities as a share of GDP. This gives us a measure of the sophistication and internationalization of the financial system. The argument is that a well developed financial system should induce more savings because higher returns are expected. On the other hand, it could also signal fewer borrowing constraints and therefore less savings. The effects on domestic investment are also not clear from a theoretical perspective. We therefore take the sign of the coefficient to be ambiguous.

- Relative income squared allows for non-linearity between relative per-capita income and current account positions (Chinn and Prasad, 2003). This is consistent with lowincome countries having little access to international capital markets, in contrast to countries in the middle stage of development. The sign of the coefficient is ambiguous.

- Asian crisis dummy. We introduce a dummy for the Asian countries, starting in 1998 and reflecting a possible structural break resulting from the impact of the financial turmoil in Asia (IMF, 2006, and Rahman, 2008). 


\subsection{Data}

We have constructed data on these 14 potential current account determinants. It is possible that only a subset of the fundamentals is relevant and we let the empirical analysis decide which are the most important determinants for the countries in the panel. ${ }^{2}$ Our main source of data is the IMF World Economic Outlook (WEO) database (September 2008 version), which provides us with data from 1980 to 2013. The time dimension thus starts in 1980, with 181 countries featuring in the WEO database. The World Development Indicators (WDI) database is used for demographic variables other than population growth, which is taken from WEO. The data on bilateral trade are taken from the IMF Direction of Trade Statistics (DOTS) database. Average foreign trade flows during the 1996-2000 period are used to compute country-specific weighted averages of foreign variables. Out of 181 countries, 172 have data on current account balances (as a percentage of GDP) over the whole of the sample period. As regards outliers, we exclude all countries with current account deficits larger than $50 \%$ at any point in time and we also exclude those countries that observed changes in the current account larger than $30 \%$ of GDP from one year to the next.

For the regressions, the time and group dimension of the panel has been selected on the basis of data availability. The minimum dimensions for which all variables are available is $N=77$ and $T=25$. Table A.1 in the Appendix describes these variables in greater detail.

\section{Estimation Techniques}

Let current account as a share of GDP in country $i$ and period $t$, denoted by $c a_{i t}$, be generated as:

$$
c a_{i t}=\alpha_{i}+\sum_{\ell=1}^{p_{i}} b_{i \ell} c a_{i, t-\ell}+\sum_{\ell=0}^{q_{i}} \mathbf{x}_{i, t-\ell}^{\prime} \boldsymbol{\delta}_{i \ell}+\epsilon_{i t},
$$

where $i \in\{1, . ., N\}, t \in\{1, . ., T\}, \mathbf{x}_{i t}$ is a $k \times 1$ dimensional vector of fundamentals for country $i$ in period $t$ and $\epsilon_{i t}$ is the error term, which is serially uncorrelated as well as uncorrelated with regressors such that $E\left(\epsilon_{i t} \mathbf{x}_{i t}\right)=\mathbf{0}$. Model (1) is a general dynamic model of current account that allows for considerable heterogeneity, both across countries via individual fixed effects $\alpha_{i}$, and, more importantly, via country-specific dynamics through heterogenous coefficients $\left\{b_{i \ell}\right\}$ and $\left\{\boldsymbol{\delta}_{i \ell}\right\}$. We assume the level relationship between current account and the set of fundamentals is homogenous; in other words that the $k \times 1$ dimensional vector of level

\footnotetext{
${ }^{2}$ We further expand this list of fundamentals, at the cost of country coverage in the sensitivity analysis.
} 
elasticities, denoted by $\phi_{i}$, is the same across countries

$$
\phi_{i}=\phi=\frac{\sum_{\ell=0}^{q_{i}} \boldsymbol{\delta}_{i \ell}}{1-\sum_{\ell=1}^{p_{i}} b_{i \ell}} \text { for any } i \in\{1, \ldots, N\}
$$

The level elasticities $\phi$ are the object of our estimations and there are a number of different approaches in the literature to estimate $\phi$ which depend on the way short-run dynamics are dealt with. Broadly speaking, the econometric techniques can be divided into two groups: $(i)$ static models (where $b_{i \ell}=0$ and $\delta_{i \ell}=0$ for $\ell>0$ ) and (ii) dynamic models. We briefly review the strengths and weaknesses of the two approaches below.

One of the major constraints in estimating the level relationship between current account and a set of fundamentals is the relatively limited number of (annual) time observations (sometimes as small as $T=10$ ), while the number of countries is relatively large, often close to a hundred. Data constraints are naturally reflected in the choice of techniques used to estimate the level relationship. The simple pooled least squares estimator suffers from a short sample bias of order $O\left(T^{-1}\right)$ in the presence of fixed effects and it is therefore typically not used in a dynamic set-up. Commonly employed estimators of dynamic current account equations are instrumental variable (IV) estimation in first differences (Anderson and Hsiao, 1982), and generalized method of moments (GMM) estimation. The former (IV) is a valid estimator of (assumed) homogenous parameters under asymptotics $N, T \rightarrow \infty$ (i.e. large $N$ and $T$ ), while the later (GMM) is valid for fixed $T$ and $N \rightarrow \infty$. Because of the relatively short time span of the available data, GMM techniques are commonly preferred. ${ }^{3}$ Examples of this approach include Bussière et al. (2006), who estimate current account benchmarks for a panel of 33 countries, including ten central and eastern European countries.

The major drawback of fixed $T$ and large $N$ estimations is that they assume homogeneity not only for the level elasticities $\boldsymbol{\phi}$, but also for all individual coefficients $b_{i \ell}=b_{\ell}$ and $\boldsymbol{\delta}_{i \ell}=\boldsymbol{\delta}_{\ell}$ for $i=1, \ldots, N$. This assumption is very unlikely to hold in practice. As shown by Pesaran and Smith (1995), in the dynamic case where the coefficients differ across groups pooling gives inconsistent and potentially highly misleading estimates of the homogenous level elasticities $\phi$. This is also true for pooled static models, which ignore dynamics altogether.

A compromise between "pure" static models and dynamic models is to filter highfrequency movements by means of $m$-year non-overlapping moving averages and then es-

\footnotetext{
${ }^{3}$ It is useful to distinguish between the "standard" GMM estimators proposed by Holtz-Eakin (1988) and Arellano and Bond (1991) and their subsequent extensions by, for example, Ahn and Schmidt (1995), Arellano and Bover (1995), and Blundell and Bond (1998). The "standard" GMM estimators are based on orthogonality conditions that interact the lagged values of the endogenous variables with first differences of the model's disturbances, whereas the "extended" GMM estimators augment these orthogonality conditions with additional moment conditions implied by homoskedasticity and initialization restrictions. More recently, Binder et al. (2005) developed GMM and QML estimators for panel VARs (fixed $T$ and $N \rightarrow \infty$ ) where it is not known whether series are stationary or $I(1)$ and possibly cointegrated.
} 
timate a static relationship between the filtered variables. As shown by Pesaran and Smith (1995), filtering the short-run dynamics by constructing non-overlapping moving averages mitigates the bias which arises if the individual country dynamics are ignored. The bias for the inference on level elasticities $\phi$ is of order $O(1 / m)$, and where $m, N \rightarrow \infty$, we have consistent estimates. Pesaran and Smith (1995) explicitly consider the case where $m=T$ and $T, N \rightarrow \infty$, that is to say a cross-sectional regression on the data averaged over time. ${ }^{4}$

In view of both the above-mentioned advantages and disadvantages, and the possibility of significant measurement errors in low frequency data, and since our focus is on medium-term developments in current accounts, we decided to filter the data first by constructing nonoverlapping time averages and then applying simple pooled OLS. ${ }^{5}$ By using this approach we are abstracting from factors that are purely cyclical or temporary. ${ }^{6}$ For the baseline we chose $m=12$, which means we average the 25 year period into 2 observations per variable. However, later in the analysis we check the sensitivity of estimations using different choices of $m$.

\subsection{Model selection}

Having decided on the choice of estimation techniques, outliers and dummies, the next major issue that needs to be addressed is the selection of regressors. Clearly, the choice of fundamentals could be crucial for the results. The strategy of using all potential explanatory variables is not necessarily optimal because of the limited size of the dataset. There is a trade-off between using potentially redundant regressors (which results in less reliable estimates) and the risk of the omitted variable problem (which can bias estimates if the omitted variable is correlated with the remaining regressors). We have compiled the data on 13 potential determinants, plus the time dummy, but it is possible that only a subset may be relevant for modelling medium-term current account movements. If all possible combinations of economic fundamentals are taken into account there are 16,384 different models to choose from. The first step is to examine all models to gauge if there are any common patterns. The second step consists in selecting the best models according to four different criteria based on economic and/or statistical considerations. We decided to use the following criteria.

\footnotetext{
${ }^{4}$ An alternative estimation technique is the pooled mean group estimator (PMG), which uses unfiltered data. PMG belongs to the class of large $T$ estimators of dynamic heterogenous panel data models, and it involves both pooling and averaging. Unlike in the IV estimations, the short run dynamics are allowed to be heterogenous across countries, only the level restriction given by equation (2) is imposed on the panel. This strategy yields consistent estimates, unlike the IV or GMM techniques described above, or simple static models. Although they are consistent, the drawback of PMG estimations is that the asymptotic guidance is likely to be less reliable where $T=25$ and there are relatively large numbers of regressors. In this case, the number of lags needs to be severely restricted and as a result it is questionable how well the dynamic behaviour is captured.

${ }^{5}$ See also Chinn and Prasad (2003) on why it is preferable to avoid fixed effects.

${ }^{6}$ Except for NFA, where we take the initial observations, as is standard in the literature.
} 
Criterion 1 We take all models with correctly signed regressors (for all fundamentals where there is a theoretical prediction for the sign) or with statistically significant regressors (for the remaining fundamentals). Finally we select the model(s) with the largest number of variables.

Criterion 2 We take all models with statistically significant and correctly signed regressors (when relevant) and then select the model(s) with the largest number of fundamentals.

Criterion 3 We rank all models in accordance with the Akaike Information Criterion (AIC). This index considers the statistical goodness of fit and imposes a penalty for the number of regressors. We then select the best model.

Criterion 4 We rank all models in accordance with the Schwarz Information Criterion (SIC). This index penalizes the addition of regressors more heavily than the AIC.

The first criterion minimizes the possibility of omitted variable bias, but it is likely that the resulting model(s) will not be parsimonious, whereas the second criterion is likely to lead to a more parsimonious specification. For these two we use the maximum available sample size. The third and fourth criteria are purely statistical. In both cases we keep the number of countries fixed at 77 , which is the common sample across all variables.

\subsection{Bayesian model combination}

Whilst the above criteria enable us to select a small subset of preferred models, none of them might be "true". An alternative approach is to attach prior probabilities to the different models and average them on the basis of the derived posterior probabilities. This is known as Bayesian Model Averaging, which allows both model and parameter uncertainty to be dealt with in a straightforward and formal way. Furthermore, the literature has shown that averaging over all the models provides better average predictive ability than using a single model.

In this paper we use the Bayesian Averaging of Classical Estimates (BACE) approach as outlined by Sala-i-Martin et al. (2004). This approach is particularly intuitive as it combines Bayesian techniques to derive the probability of each model with classical ordinary least square (OLS) estimates of such models. While referring to Sala-i-Martin et al. (2004) for the complete derivation, we briefly sketch here some key features. Let us define $P\left(M_{j}\right)$ as the prior probability that $M_{j}$ is the true model. The posterior probability of each model $M_{j}$, can then be expressed as 


$$
P\left(M_{j} / y\right)=\frac{l_{y}\left(M_{j}\right) P\left(M_{j}\right)}{\sum_{i=1}^{2^{K}} l_{y}\left(M_{i}\right) P\left(M_{i}\right)},
$$

where $l_{y}\left(M_{j}\right)$ is the likelihood of model $M_{j}$ given data $y$ and the number of candidate regressors $K$.

A potentially important issue is to determine the prior probabilities of the models, $P\left(M_{j}\right)$. In contrast to a standard Bayesian approach that requires the specification of a prior distribution for all parameters, the BACE approach requires the specification of only one prior hyper-parameter: the expected model size $k$. Sala-i-Martin et al. (2004) propose choosing a prior mean model size, $k$, with each variable having a prior probability $k / K$ of being included. ${ }^{7}$ The posterior probability of each model $M_{j}$ can then be used to simply select the "best" model by choosing the one with highest posterior probability. The posterior probability of each model estimated in this way is a function of the goodness of fit of the model defined using a standard measure, the Schwarz criterion, and includes a degrees-of-freedom correction to take account of the fact that models with more variables have a lower sum of squared errors. Given that the strategy of using only the best model seems on average to predict worse than model averaging, it is, therefore, generally preferred to use $P\left(M_{j} / y\right)$ as weights.

\section{Empirical findings}

Before dealing with model selection we consider the whole range of estimated models. Taking all permutations of our 14 variables gives us 16,384 models. Figure 1 shows the distribution of the estimated coefficients for each variable whenever it appears in one of the regressions. Although in several of these regressions the estimated coefficients will not be significant, these histograms give an idea of the uncertainty surrounding the contribution of each variable to explaining structural current accounts, i.e. a measure of parameter uncertainty.

\footnotetext{
${ }^{7}$ Ley and Steel (2009) have shown that differences can arise from having a random rather than a fixed hyper-parameter. However, using a fixed hyper-parameter is the standard prior used in the model averaging literature as it is an uninformative prior that is easy to interpret, easy to specify, and easy to check for robustness (which we do in Appendix B).
} 

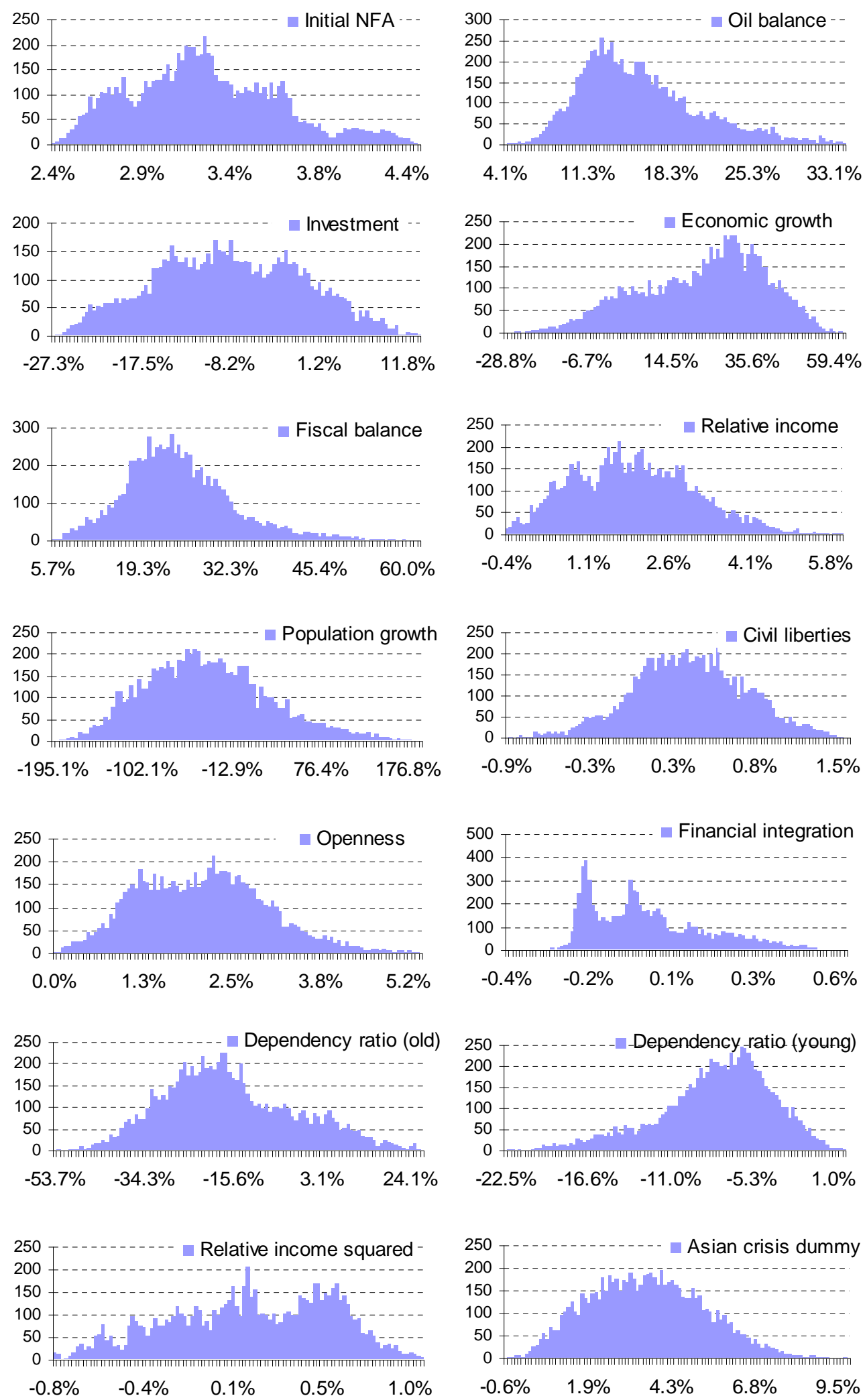

Figure 1: Histograms of coefficient estimates. 
For some variables the coefficients are bound in a relatively tight range (e.g. NFA from $2.4 \%$ to $4.4 \%$ ), whereas others have a larger range with both positive and negative coefficients. For most variables, there is a clear tendency to either positive or negative values with a unimodal distribution, i.e. the sign of the coefficient appears robust across almost all options. The only variable with a distribution different from what we expected is relative GDP growth, where only a few models have the expected negative sign, and the vast majority have a positive sign; this is discussed in more detail below.

After making our selection, we narrowed down the analysis to eight models. These, along with the model average (BACE) results are presented in Table 1 (Criterion 1) and Table 2 (remaining models).

The first observation to be made on the table is that each selection criterion produces different models. The first selection criterion shows 5 models where (i) all variables for which we had a prior show the correct sign, (ii) the other variables are significant, and (iii) the requirement of having the largest number of variables (in this case 11) is met. With the second selection criterion, which also foresees all variables being significant, the maximum number of variables in a regression meeting these requirements is 8, and only one model is feasible. For these two criteria, the number of countries modeled ranged from 77 to 99 , reflecting the maximum country availability given the data. For the next two criteria and the BACE method, the span of the time series was kept constant at the common sample of 77 countries to enable model comparability. Under the third selection method, the AIC based criterion, a model with 11 variables was chosen, whereas for the fourth, the Schwarz criterion, only 4 variables were selected. This is in line with the theory, whereby the AIC criterion assigns a smaller penalty to the number of regressors than the Schwarz criterion. Nonetheless, the AIC-based model is notable in that the regression selected has 11 variables and most of the signs are consistent with our priors.

Examination of the variables selected using the 4 different criteria reveals that NFA is selected in all reported specifications, with a tightly bound coefficient ranging from 0.025 to 0.031 , and is in all cases highly significant. Another variable to feature in almost all regressions is the oil balance, where the coefficient ranges from 0.083 to 0.158 . The coefficient estimate for relative income ranges between 0.007 and 0.039 . As the textbooks suggest, all other things being equal countries in the early stages of development should be greater recipients of capital. In the panel current account literature, however, the sign is often counter-intuitive or, as in our case, small (Rahman, 2008, IMF 2006, Chinn and Prasad, 2003). ${ }^{8}$ The fact that economic growth does not feature in any of the regressions other than that selected using the AIC-based criterion is of particular relevance. The reason becomes

\footnotetext{
${ }^{8}$ This is in line with the Lucas paradox, which holds that capital does not flow from the "rich" to the "poor"; see discussion in Reinhard and Rogoff (2004).
} 
Table 1: Fundamentals and estimated elasticities for the selected models under Criterion $1(m=12)$.

\begin{tabular}{|c|c|c|c|c|c|}
\hline \multirow[b]{2}{*}{ No of variables: } & \multicolumn{5}{|c|}{ Criterion 1} \\
\hline & 11 & 11 & 11 & 11 & 11 \\
\hline Variable & Model 1 & Model 2 & Model 3 & Model 4 & Model 5 \\
\hline \multirow{2}{*}{ Initial NFA } & 0.029 & 0.031 & 0.025 & 0.026 & 0.030 \\
\hline & $(5.8)$ & $(6.7)$ & $(3.9)$ & $(4.4)$ & $(6.3)$ \\
\hline \multirow[t]{2}{*}{ Oil balance } & 0.083 & 0.128 & 0.099 & & 0.137 \\
\hline & $(1.4)$ & $(1.8)$ & $(2.2)$ & & $(2.0)$ \\
\hline \multirow[t]{2}{*}{ Investment } & -0.091 & -0.111 & -0.027 & -0.041 & -0.061 \\
\hline & $(-1.5)$ & $(-1.8)$ & $(-0.5)$ & $(-0.7)$ & $(-0.9)$ \\
\hline \multicolumn{6}{|l|}{ Economic growth } \\
\hline \multirow[t]{2}{*}{ Fiscal balance } & 0.159 & 0.214 & & & 0.171 \\
\hline & $(1.7)$ & $(2.5)$ & & & $(1.9)$ \\
\hline \multirow[t]{2}{*}{ Relative income } & 0.033 & 0.007 & 0.018 & 0.028 & 0.016 \\
\hline & $(3.5)$ & $(1.4)$ & $(2.1)$ & $(3.4)$ & $(1.9)$ \\
\hline \multirow[t]{2}{*}{ Population growth } & -1.387 & -0.931 & -1.198 & -1.164 & -0.895 \\
\hline & $(-2.6)$ & $(-1.6)$ & $(-2.5)$ & $(-2.5)$ & $(-1.7)$ \\
\hline \multirow[t]{2}{*}{ Civil liberties } & 0.006 & 0.005 & & 0.003 & 0.005 \\
\hline & $(2.9)$ & $(2.1)$ & & $(1.3)$ & $(2.3)$ \\
\hline \multirow[t]{2}{*}{ Openness } & & 0.013 & 0.019 & 0.020 & 0.016 \\
\hline & & $(2.1)$ & $(2.4)$ & $(2.4)$ & $(2.6)$ \\
\hline \multirow[t]{2}{*}{ Financial. integration } & & & -0.002 & -0.002 & \\
\hline & & & $(-2.4)$ & $(-2.0)$ & \\
\hline \multirow[t]{2}{*}{ Dependency ratio (old) } & -0.329 & -0.192 & -0.280 & -0.329 & \\
\hline & $(-3.9)$ & $(-2.6)$ & $(-3.4)$ & $(-4.1)$ & \\
\hline \multirow[t]{2}{*}{ Dependency ratio (young) } & -0.036 & -0.058 & -0.038 & -0.036 & -0.022 \\
\hline & $(-1.4)$ & $(-2.3)$ & $(-1.4)$ & $(-1.4)$ & $(-0.8)$ \\
\hline \multirow[t]{2}{*}{ Relative income squared } & 0.008 & & 0.006 & 0.008 & 0.005 \\
\hline & $(2.9)$ & & $(2.8)$ & $(3.7)$ & $(2.1)$ \\
\hline \multirow[t]{2}{*}{ Asian crisis dummy } & 0.038 & 0.033 & 0.012 & 0.015 & 0.035 \\
\hline & $(2.0)$ & $(1.6)$ & $(0.6)$ & $(0.8)$ & $(1.8)$ \\
\hline No of countries & 77 & 77 & 98 & 99 & 77 \\
\hline No of observations & 1925 & 1925 & 2450 & 2475 & 1925 \\
\hline Data shrinkage & 154 & 154 & 196 & 198 & 154 \\
\hline Adjusted $\mathrm{R}^{2}$ & 59.0 & 56.9 & 45.4 & 43.6 & 56.9 \\
\hline
\end{tabular}

Notes: Pooled ordinary least squares (OLS) estimation on the non-overlapping 12-year moving averages. Robust t-ratios are reported in parentheses. 
Table 2: Fundamentals and estimated elasticities for the selected models under Criterion 2-4 and BACE $(m=12)$.

\begin{tabular}{|c|c|c|c|c|}
\hline \multirow{3}{*}{$\begin{array}{c}\text { No of variables (or prior): } \\
\text { Variable }\end{array}$} & Criterion. 2 & Criterion. 3 & Criterion. 4 & BACE \\
\hline & 8 & 11 & 4 & 5 \\
\hline & Model 6 & Model 7 & Model 8 & Model 9 \\
\hline \multirow[t]{2}{*}{ Initial NFA } & 0.025 & 0.030 & 0.031 & 0.033 \\
\hline & $(4.1)$ & $(6.4)$ & $(5.9)$ & $(6.3)$ \\
\hline \multirow[t]{2}{*}{ Oil balance } & 0.096 & 0.089 & 0.158 & 0.164 \\
\hline & $(2.1)$ & $(1.3)$ & $(3.4)$ & $(2.6)$ \\
\hline \multirow[t]{2}{*}{ Investment } & & -0.091 & & -0.022 \\
\hline & & $(-1.3)$ & & $(-0.3)$ \\
\hline \multirow[t]{2}{*}{ Economic growth } & & 0.327 & & 0.404 \\
\hline & & $(1.8)$ & & $(1.1)$ \\
\hline \multirow[t]{2}{*}{ Fiscal balance } & & & & 0.242 \\
\hline & & & & $(1.1)$ \\
\hline \multirow[t]{2}{*}{ Relative income } & 0.022 & 0.039 & & 0.022 \\
\hline & $(2.7)$ & $(5.8)$ & & $(1.0)$ \\
\hline \multirow[t]{2}{*}{ Population growth } & -1.522 & -1.539 & & -1.052 \\
\hline & $(-3.6)$ & $(-3.9)$ & & $(-1.2)$ \\
\hline \multirow[t]{2}{*}{ Civil liberties } & & 0.006 & & 0.007 \\
\hline & & $(2.9)$ & & $(1.0)$ \\
\hline \multirow[t]{2}{*}{ Openness } & 0.020 & & 0.019 & 0.021 \\
\hline & $(2.7)$ & & $(3.7)$ & $(1.8)$ \\
\hline \multirow[t]{2}{*}{ Financial integration } & -0.002 & 0.004 & & 0.004 \\
\hline & $(-2.4)$ & $(1.7)$ & & $(0.8)$ \\
\hline \multirow[t]{2}{*}{ Dependency ratio (old) } & -0.254 & -0.329 & & -0.199 \\
\hline & $(-3.4)$ & $(-4.0)$ & & $(-0.9)$ \\
\hline \multirow[t]{2}{*}{ Dependency ratio (young) } & & & -0.053 & -0.058 \\
\hline & & & $(-4.1)$ & $(-1.7)$ \\
\hline \multirow[t]{2}{*}{ Relative income squared } & 0.006 & 0.010 & & 0.007 \\
\hline & $(3.0)$ & $(4.3)$ & & $(1.0)$ \\
\hline \multirow[t]{2}{*}{ Asian crisis dummy } & & 0.035 & & 0.054 \\
\hline & & $(1.7)$ & & $(1.1)$ \\
\hline No of countries & 99 & 77 & 77 & 77 \\
\hline No. of observations & 2475 & 1925 & 1925 & 1925 \\
\hline Data shrinkage & 198 & 154 & 154 & 154 \\
\hline Adjusted $\mathrm{R}^{2}$ & 44.6 & 60.3 & 50.3 & - \\
\hline
\end{tabular}

Notes: Pooled ordinary least squares (OLS) estimation on the non-overlapping 12-year moving averages. Robust t-ratios are reported in parentheses. BACE results are for a prior of inclusion of 5 variables and the elasticities reported are conditional on the variable being included. 
clear from the histogram, which shows that for nearly all the regressions economic growth comes up with a positive sign. There is thus little empirical support that strong growth is associated with current account deficits. By contrast, openness, the sign for which was considered to be ambiguous, has a positive coefficient in all six models where it appears. Fiscal balance, relative income, civil liberties and the demographic variables are always selected with the correct sign, featuring to a greater or lesser extent in all eight selected models.

Turning to the remaining variables, both financial integration and investment have limited explanatory power, the former appearing in four of the selected regressors but with a small coefficient, while the latter is never significant. For relative income squared we did not have a clear-cut expectation about the sign ex-ante. Whilst the distribution was centred around zero, in the selected models where it appears the sign is positive. The dummy for the Asian crisis proves to be significant in almost all models and the coefficient is always positive.

It is also noteworthy that none of the coefficients in these models are at the extremes of the distributions in Figure $1,{ }^{9}$ and that the estimates are in line with other estimates in the literature. $^{10}$

The analysis carried out so far suggests there are a number of models that could be selected to provide current account benchmarks, and our results provide some measure of the uncertainty surrounding the estimates. Rather than focusing on one or two models which might be mis-specified, the alternative is to carry out a model combination exercise which takes advantage of the full range of possible models. The last column of Table 2 reports the BACE results for the case of a hyper-prior of 5 variables. The coefficients and t-statistics are the posterior mean and standard deviations conditional on the variable being included in the regression; these coefficients can therefore be considered comparable to the coefficients from the single regressions (Models 1 to 8 ). The coefficients for the BACE are similar to the range of coefficients in Models 1 to 8, with NFA and oil balance being the only coefficients with t-statistics greater than or equal to 2 .

\subsection{Sensitivity analysis of level elasticities}

To check the sensitivity of our analysis we look at the level elasticitites derived using BACE by (i) varying the temporal aggregation window, (ii) considering an alternative selection of countries and (iii) expanding the set of plausible fundamentals.

Table 3 shows that the BACE estimation results are broadly robust to different temporal aggregation windows. In particular the coefficient for NFA is in the narrow range between

\footnotetext{
${ }^{9}$ Similar conclusions would be reached if the histograms were presented in terms of common rather than maximum available sample.

${ }^{10}$ For an overview of the results of other main studies see Table 2 in Rahman (2008).
} 
0.033 and 0.036 for $m \leq 12$, although it is considerably higher for $m=25$. The range is relatively contained for the other significant variable, namely oil balance, for which the coefficient is between 0.1 and 0.16 . For most other variables the coefficients are not significant. For temporal aggregation windows of 1 or 4 periods, investment and fiscal balance have greater explanatory power; this would appear to be intuitive as these fundamentals play a larger role in short term horizons.

The issue of homogeneity of elasticities across different grouping of countries is also frequently discussed in the literature. Table A.2 in the Appendix shows the robustness of BACE results to different samples excluding G7, Latin America, emerging Asia, the Middle East and euro area countries. In most cases the results are similar, although the analysis appears to be more sensitive to the exclusion of the Middle East. Table A.3 in the Appendix also demonstrates the robustness of the BACE results to splitting the sample approximately into two halves, either between high and low-income countries or between countries with high and low NFA positions. We discuss later to what extent this has an impact on the assessment of global imbalances.

Ley and Steel (2009) have also shown that results could be sensitive to alternative hyperpriors. We report, in Appendix B, the posterior probabilities of including variables across the full set of hyper-priors. NFA positions and the oil balance remain the key variables, and the main thrust of our analysis on imbalances is unchanged.

Finally, even if we adopted a comprehensive approach consistent with thousands of models, the set of macroeconomic variables could still be further expanded. The initial choice of variables to be included in the analysis was based on our reading of the literature on the key determinants of the current account over the medium-term horizon. Additional variables could be nonetheless envisaged beyond those considered above; however, this would come at the cost of a reduced sample size as data is not available for all countries. To check the sensitivity of including an extended set of regressors, we added 8 variables.

- Real effective exchange rate. Price competitiveness plays an important role in explaining short-run current account transactions. It is, however, not included as a medium-term determinant of current account benchmarks in IMF (2006) and is generally not included for $m>4$. In fundamental equilibrium exchange rate models the price competitiveness channel is perceived as playing a pivotal role in bringing cycle-adjusted current account positions back to the benchmarks (Bussière et al, 2010).

- Chinn-Ito index. As capital controls are eased, external financing may support current account deficits (Chinn and Prasad, 2003, and De Santis and Lührmann, 2008). In this paper we rely on a measure of financial openness developed recently by Chinn and Ito (2008). 
Table 3: Robustness of BACE estimation results to different temporal aggregation windows.

\begin{tabular}{|c|c|c|c|c|}
\hline & \multicolumn{4}{|c|}{ Temporal aggregation window } \\
\hline & $m=1$ & $m=4$ & $m=12$ & $m=25$ \\
\hline \multirow[t]{2}{*}{ 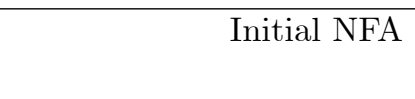 } & 0.036 & 0.036 & 0.033 & 0.063 \\
\hline & $(8.5)$ & $(6.8)$ & $(6.3)$ & $(3.5)$ \\
\hline \multirow{2}{*}{ Oil balance } & 0.133 & 0.127 & 0.164 & 0.100 \\
\hline & $(3.1)$ & $(2.7)$ & $(2.6)$ & $(1.2)$ \\
\hline \multirow[t]{2}{*}{ Investment } & -0.167 & -0.129 & -0.022 & 0.001 \\
\hline & $(-4.9)$ & $(-3.1)$ & $(-0.31)$ & $(0.0)$ \\
\hline \multirow[t]{2}{*}{ Economic growth } & -0.043 & 0.033 & 0.404 & 0.141 \\
\hline & $(-0.8)$ & $(0.3)$ & $(1.1)$ & $(0.6)$ \\
\hline \multirow[t]{2}{*}{ Fiscal balance } & 0.252 & 0.261 & 0.242 & 0.211 \\
\hline & $(4.7)$ & $(4.2)$ & $(1.1)$ & $(1.1)$ \\
\hline \multirow[t]{2}{*}{ Relative income } & -0.003 & 0.000 & 0.022 & 0.004 \\
\hline & $(-0.5)$ & $(0.1)$ & $(1.0)$ & $(0.4)$ \\
\hline \multirow[t]{2}{*}{ Population growth } & -0.493 & -0.722 & -1.052 & -0.134 \\
\hline & $(-3.1)$ & $(-1.2)$ & $(-1.2)$ & $(-0.3)$ \\
\hline \multirow[t]{2}{*}{ Civil liberties } & 0.003 & 0.003 & 0.007 & 0.000 \\
\hline & $(1.1)$ & $(0.8)$ & $(1.0)$ & $(0.2)$ \\
\hline \multirow[t]{2}{*}{ Openness } & 0.018 & 0.016 & 0.021 & 0.013 \\
\hline & $(3.3)$ & $(3.0)$ & $(1.8)$ & $(1.1)$ \\
\hline \multirow[t]{2}{*}{ Financial integration } & 0.000 & 0.001 & 0.004 & 0.000 \\
\hline & $(-0.1)$ & $(0.5)$ & $(0.8)$ & $(0.2)$ \\
\hline \multirow[t]{2}{*}{ Dependency ratio (old) } & -0.121 & -0.151 & -0.199 & -0.062 \\
\hline & $(-1.9)$ & $(-1.2)$ & $(-0.9)$ & $(-0.5)$ \\
\hline \multirow[t]{2}{*}{ Dependency ratio (young) } & -0.053 & -0.057 & -0.058 & -0.018 \\
\hline & $(-2.8)$ & $(-2.1)$ & $(-1.7)$ & $(-0.5)$ \\
\hline \multirow[t]{2}{*}{ Relative income squared } & 0.002 & 0.002 & 0.007 & 0.000 \\
\hline & $(0.8)$ & $(0.7)$ & $(1.0)$ & $(0.1)$ \\
\hline \multirow[t]{2}{*}{ Asian crisis dummy } & 0.048 & 0.048 & 0.054 & 0.007 \\
\hline & $(3.6)$ & $(3.1)$ & $(1.1)$ & $(0.3)$ \\
\hline No of countries & 77 & 77 & 77 & 77 \\
\hline No of observations & 1925 & 1925 & 1925 & 1925 \\
\hline Data shrinkage & 1925 & 462 & 154 & 77 \\
\hline
\end{tabular}

Notes: Pooled ordinary least squares estimation on the non-overlapping $m$-year moving averages. Robust t-ratios are reported in parentheses. BACE results are for a prior of inclusion of 5 variables and the elasticities reported are conditional on the variable being included. 
- Financial sector reform. Financial reforms help relax borrowing constraints affecting savings. We use the measure developed by Abiad et al. (2008), which aggregates several different indicators of financial sector policy. We prefer this measure to alternative financial deepening measures, as it is broadly based and has better cross-country comparability.

- Capital gains. Gourinchas and Rey (2007) and others have suggested that valuation effects play an important role as price and exchange rate fluctuations lead to sizable volatility in wealth, especially in the short-run. While the literature has discussed extensively whether the United States enjoys an exorbitant privilege and could afford larger current account and trade deficits over the medium-term (e.g. Eichengreen 2006, Gourinchas and Rey 2007, Gourinchas 2008, Gourinchas et al 2010), the issue might be relevant for other countries and globally (Lane and Milesi-Ferretti 2005a, 2005b, Hausmann and Sturzenegger, 2007, Habib, 2010). ${ }^{11}$ We included capital gains for the broad range of countries in our sample using the decomposition proposed by Lane and Milesi-Ferretti (2005b). ${ }^{12}$

- Terms of trade. The current account performance of a country may also be affected by the ratio of export to import prices (Chinn and Prasad, 2003).

- Deviation from uncovered interest rate parity (UIP). A rise in foreign exchange premia signals higher external financing costs, which may have repercussions for the current account (De Santis and Lührmann, 2008).

- Financial center dummy. Financial centers generally have strong creditor positions and current account surpluses. We set the dummy equal to 1 for the same countries as in IMF (2006). The exclusion of the United Kingdom (which does not fit this intuition) could be seen as arbitrary, however.

- Banking crisis dummy. As discussed in IMF (2006), banking crises affect the ability of a country to finance external deficits. We set the dummy equal to 1 in the year of the crisis and the two following years, assuming that full access to capital markets is resumed thereafter. The dating of the crises comes from Laeven and Valencia (2008).

\footnotetext{
${ }^{11}$ The theoretical links and normative interpretations are not trivial. While higher capital gains from foreign holdings (relative to domestic) help stabilize the stock of external debt, they could also reflect a structural weakness of the economy (Eichengreen, 2006) or a large exposure to asset-liability mismatch risk in times of financial turbulence (Gourinchas et al, 2010).

${ }^{12}$ Capital gains were on average over the sample 1980-2007 found to be over 1\% of GDP for the United States and close to zero for the United Kingdom, Japan and China. Although severely affected by measurament error and potentially capturing other factors, such as debt restructuring, we tested the implications of including/excluding this variable from the baseline and from the extended set of regressors; we found that the main thrust of the analysis remains unchanged. Future research may, however, be warranted to further assess the role of valuation effects at the global level and not just for the United States.
} 
The "cost" of having such an extended set of regressors is a significant drop in the common sample size, from 77 countries in the baseline to 36 countries, while the number of feasible model combinations rises to over 4 million. The loss of observations and the rise in model uncertainty lead to a significant drop in t-values (Table A.3). As discussed later, however, this does not prevent us from reaching clear-cut conclusions on the current account constellation prevailing before the crisis.

\section{Implications for Global Imbalances}

We apply the main implications of our results to four major economies, namely the United States, the United Kingdom, Japan and the People's Republic of China. We start with a snapshot of current account benchmarks in 2007 by considering all possible models with $m=12$ derived from the baseline set of regressors. The vast majority of models suggest that current account deficits should be expected for the United States, the United Kingdom and Japan. According to the peaks in the distributions, these deficits should be close to $3 \%$ of GDP for the United States while lower values of about 1.5 and $2 \%$ of GDP are found for the United Kingdom and Japan respectively (Figure 2, upper panel). In the case of China, a large number of models point to current account surpluses of between 1.5 and $3 \%$ of GDP, even if there are a few models consistent with relatively large deficits.

A second set of histograms is derived by using the extended sample of regressors (Figure 2, lower panel). Although reflecting millions of models and a smaller country coverage, the peaks still point to a moderate deficit in the United States, the United Kingdom and Japan and to a moderate surplus in China.

To gauge the evolution of global imbalances we refer to the three econometric strategies outlined earlier, that is to (i) examine where the large majority of models are clustered, (ii) select a specific model, and (iii) apply model averaging using BACE. We only report the results for the baseline as those for the extended sample are entirely analogous. 
A. Baseline set of regressors (large country coverage)
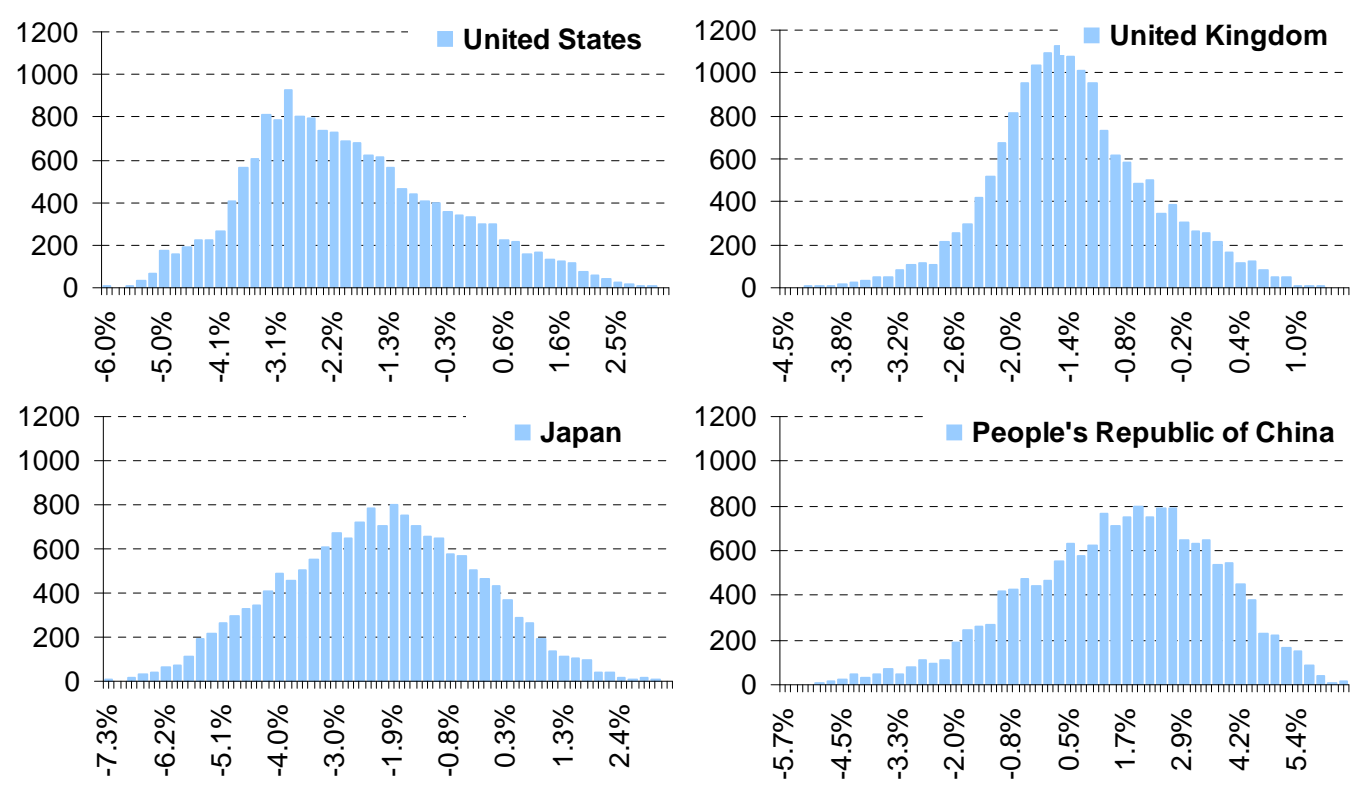

B. Extended set of regressors (smaller country coverage)
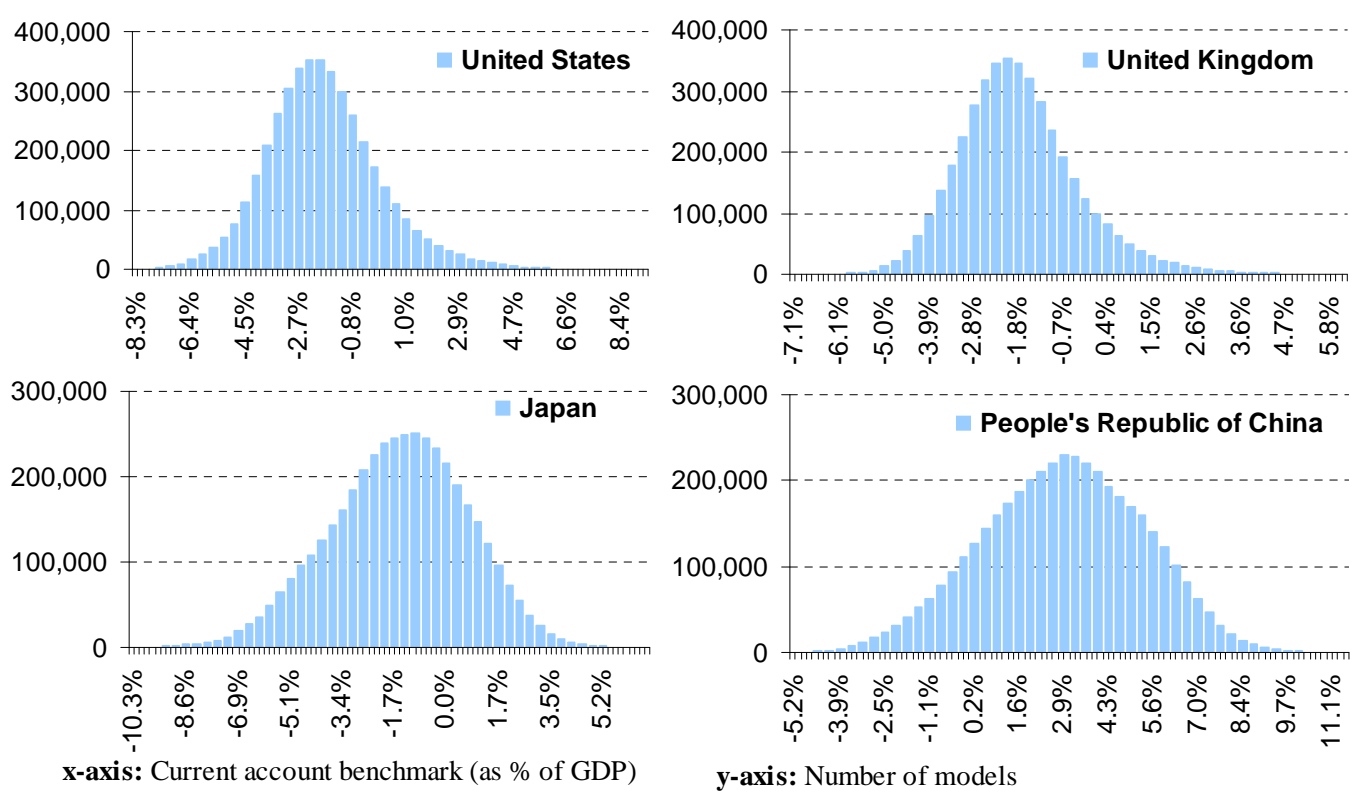

Figure 2: Current account benchmarks in 2007.

The first approach is to derive current account benchmarks from all models and compare them to actual current account realizations (Figure 3). Obviously, this approach cannot always reach univocal conclusions, particularly as some of the models could be mis-specified. However, as the implied current account benchmarks between the $10 \%$ and $90 \%$ quantiles are located within a relatively narrow range, a clear story emerges. Almost all the models suggest that prior to the financial crisis the increase in current account deficits in the United 
States and the United Kingdom and the growing surpluses in Japan and China could not easily be reconciled with the evolution of economic fundamentals. However, towards the end of the forecast horizon this conclusion is less clear-cut for the United States and the United Kingdom (taking WEO projections). ${ }^{13}$
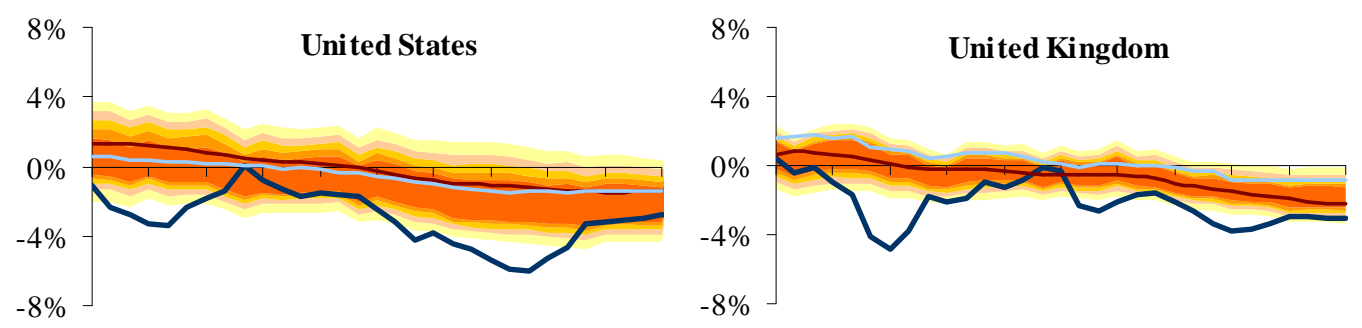

$\begin{array}{lllllllllll}83 & 86 & 89 & 92 & 95 & 98 & 01 & 04 & 07 & 10 & 13\end{array}$

$\begin{array}{lllllllllll}83 & 86 & 89 & 92 & 95 & 98 & 01 & 04 & 07 & 10 & 13\end{array}$
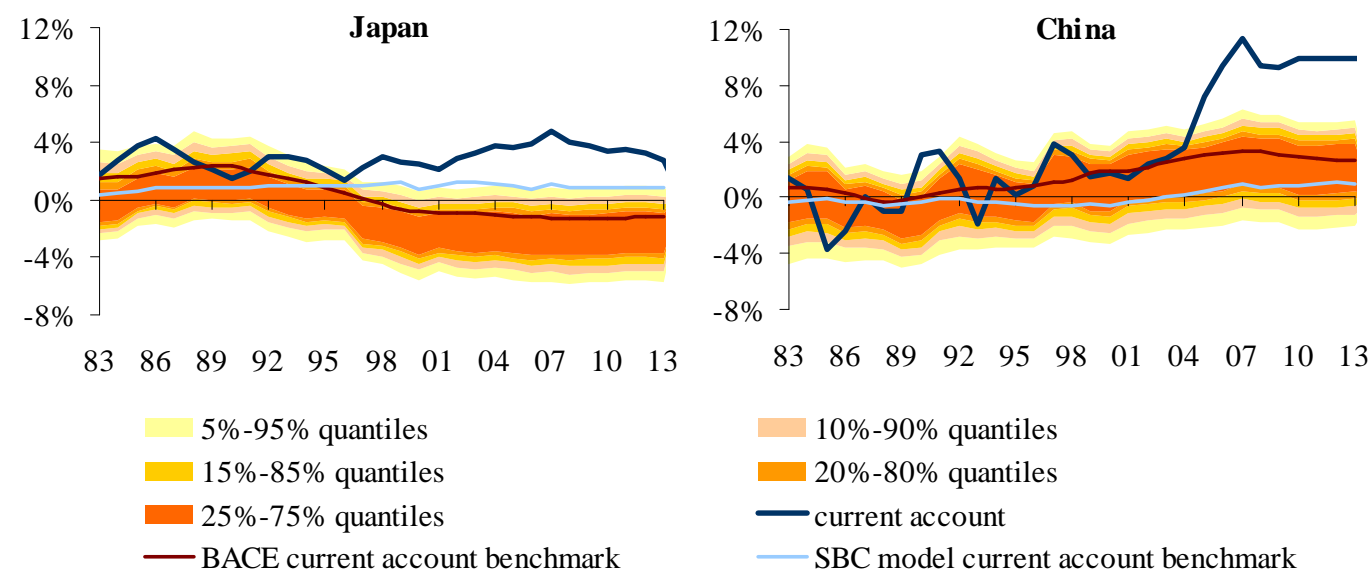

Figure 3: Current account benchmarks

The second approach - looking at a particular selected model - allows one to quantify the extent of the imbalances. In Figure 3 we plot the benchmark based on the Schwarz (SBC) criterion (model 8). This model suggest that current accounts were not aligned with fundamentals in the global economy in 2007, with imbalances of around $10 \%$ for China, $5 \%$ for the United States, and slightly less for the United Kingdom and Japan.

The third approach to analyzing imbalances is to rely on model combination techniques, such as BACE, which uses the information content of all models but weights them on the basis of their statistical properties. This approach avoids the danger of drawing too many conclusions on the basis of one specific and potentially mis-specified model. As shown in Figure 3, the BACE current account benchmark ${ }^{14}$ is always contained in the min-max bounds across the $25 \%$ and $75 \%$ quantiles but is not necessarily close to the middle point. It signals

\footnotetext{
${ }^{13}$ We take the WEO September 2008 set of projections for both the current account and all available fundamentals; we assume unchanged fundamentals for the remaining variables.

${ }^{14}$ The unconditional coefficients of the BACE model are derived by rescaling the conditional coefficients using the probabilities in Table B.1 in the Appendix.
} 
that in 2007 there were large imbalances in all four countries of interest. By the end of the forecast horizon, this benchmark suggests that imbalances would narrow for the United States and the United Kingdom but not for China and Japan.

The analysis is then taken one step forward by calculating the probability that the current account position of any given country is misaligned, see Table $4 .{ }^{15}$ For the baseline the results are clear cut. The probability that current account deficits were too large in 2007 is, depending on the temporal aggregation window, between $70 \%$ and $93 \%$ for the United States and between $63 \%$ to $81 \%$ for the United Kingdom. Similarly, the probability of current account surpluses in China and Japan being above the 2007 benchmarks is over $95 \%$ for all temporal aggregations.

Table 4: Probabilities of misalignment

\begin{tabular}{|c|c|c|c|c|c|}
\hline & \multicolumn{4}{|c|}{2007} & \multirow{2}{*}{$\begin{array}{r}2013 \\
\mathrm{~m}=12\end{array}$} \\
\hline & $\mathrm{m}=1$ & $\mathrm{~m}=4$ & $\mathrm{~m}=12$ & $\mathrm{~m}=25$ & \\
\hline & \multicolumn{5}{|c|}{$P(\mathrm{CA}$ deficit $<$ benchmark $)$} \\
\hline United States & 0.70 & 0.75 & 0.93 & 0.80 & 0.71 \\
\hline \multirow[t]{2}{*}{ United Kingdom } & 0.63 & 0.65 & 0.81 & 0.67 & 0.57 \\
\hline & \multicolumn{5}{|c|}{$P(\mathrm{CA}$ surplus $>$ benchmark $)$} \\
\hline Japan & 0.96 & 0.98 & 0.99 & 0.98 & 0.95 \\
\hline People's Republic of China & 0.97 & 0.99 & 0.95 & 0.97 & 0.96 \\
\hline
\end{tabular}

The combined information content from this modelling approach and the WEO forecast database point to a likely persistence of current account imbalances in Japan and China in 2013, while the evidence for the United States and the United Kingdom (Table 4) is weaker.

We finally consider to what extent these conclusions concerning current account imbalances are robust to the sensitivity analysis we conducted earlier. By splitting the baseline into two subsamples, either by income or NFA levels, our general assessment for any of the four countries does not change (Table 5). Taking the extended model - which reduces the sample of countries to 36 and increases the number of models from over 16,000 to more than 4 million - provides further evidence that current account surpluses were too large in Japan and China in 2007; the evidence of a misalignment is less strong in the case of the United States and the United Kingdom.

\footnotetext{
${ }^{15}$ This is achieved with the following two step procedure. First, conditional on each model being the "true" model, we derive the probability that the current account exceeds its fitted value, namely that $P\left(c a_{i t}>\widehat{c a} a_{i t} / y, M_{j}\right)$. Using Bayes' rule, the probability that the current account exceeds its fitted value, considering model uncertainty, is $P\left(c a_{i t}>\widehat{c a}_{i t} / y\right)=\sum_{j=1}^{2^{K}} P\left(M_{j} / y\right) P\left(c a_{i t}>\widehat{c a}_{i t} / y, M_{j}\right)$.
} 
Table 5: Probabilities of misalignment in 2007, sensitivity analysis

\begin{tabular}{|c|c|c|c|c|}
\hline \multirow[b]{2}{*}{ Country sample: } & \multicolumn{3}{|c|}{$\begin{array}{l}\text { Standard set } \\
\text { (14 variables) }\end{array}$} & \multirow{2}{*}{$\begin{array}{c}\text { Extended set } \\
(22 \text { variables }) \\
36\end{array}$} \\
\hline & 77 & Split by income & Split by NFA & \\
\hline & \multicolumn{4}{|c|}{$P(\mathrm{CA}$ deficit $<$ benchmark $)$} \\
\hline United States & 0.93 & 0.73 & 0.94 & 0.87 \\
\hline \multirow[t]{2}{*}{ United Kingdom } & 0.81 & 0.88 & 0.92 & 0.73 \\
\hline & \multicolumn{4}{|c|}{$P(\mathrm{CA}$ surplus $>$ benchmark $)$} \\
\hline Japan & 0.99 & 0.99 & 0.97 & 0.96 \\
\hline People's Republic of China & 0.95 & 0.99 & 0.98 & 0.99 \\
\hline
\end{tabular}

Note: For $m=12$.

\section{Concluding Remarks}

Current account imbalances are said to have been an important root cause of the global financial turmoil. This paper has shown that there are thousands, if not millions, of models, which may lead to different conclusions on whether disequilibria exist and their size. To reach policy conclusions we explored different routes, corresponding to three alternative plausible econometric strategies: examining all models, selecting a few, and combining them all. Whether we take the cluster where the largest number of models can be found, select the best model according to both statistical and economic criteria, or combine all models, the same conclusion can be reached: current account imbalances prevailed in all four countries (the United Kingdom, the United States, Japan and China) prior to the crisis. Although models could be selected that result in different benchmarks, one has to assess how likely it is that they are mis-specified. We have therefore turned the analysis into a single probability statement, which accounts for both the likelihood of models being "true" and estimation uncertainty. Out of thousands/millions of models, one consistent story emerges. The chance that current accounts were aligned with fundamentals prior to the financial crisis appears to be, according to this approach, minimal. 


\section{References}

[1] Abiad, A., Detragiache, E., Tressel, T., 2008. A new database of financial reforms. IMF Working Paper No. 08/266. Washington, DC.

[2] Ahn, S., Schmidt, P., 1995. Efficient estimation of a model with dynamic panel data. Journal of Econometrics 68, 5-27.

[3] Anderson, T.W., Hsiao, C., 1982. Formulation and estimation of dynamic models using panel data. Journal of Econometrics 18, 47-82.

[4] Arellano, M., Bond, S., 1991. Some tests of specification for panel data: Monte Carlo evidence and an application to employment equations. Review of Economic Studies 58, 277-297.

[5] Arellano, M., Bover, S., 1995. Another look at the instrumental variable estimation of errorcomponent models. Journal of Econometrics 68, 29-51.

[6] Aristovnik, A., 2006. The determinants and excessiveness of current account deficits in Eastern Europe. William Davidson Institute Working Paper No 827.

[7] Bergin, P., 2006. How well can the new open economy macroeconomics explain the exchange rate and current account. Journal of International Money and Finance 25, 675-701.

[8] Bergin, P., Sheffrin, S., 2000. Interest rates, exchange rates and present value models of the current account. The Economic Journal 110, 535-558.

[9] Binder, M., Hsiao, C., Pesaran, M.H., 2005. Estimation and inference in short panel vector autoregressions with unit roots and cointegration. Econometric Theory 21, 795-837.

[10] Blanchard, O., Milesi-Ferretti G.M., 2009. Global imbalances: in midstream? IMF Staff Position Note SPN/09/29.

[11] Blundell, R., Bond, S., 1998. Initial conditions and moment restrictions in dynamic panel data models. Journal of Econometrics 87, 115-144.

[12] Bussière, M., Fratzscher, M., Muller, G., 2006. Current account dynamics in OECD and new EU member states: an intertemporal approach. Journal of Economic Integration 21 (3), 593618.

[13] Bussière, M., Ca’ Zorzi, M., Chudik, A., Dieppe, A., 2010. Methodological advances in the assessment of equilibrium exchange rates. ECB Working Paper No. 1151. Frankfurt

[14] Ca' Zorzi, M., Rubaszek, M., 2008. On the empirical evidence of the intertemporal current account model for the euro area. ECB Working Paper No. 895. Frankfurt.

[15] Ca' Zorzi, M., Chudik, A., Dieppe, A., 2011. And then current accounts (over)adjusted. Empirical Economics, forthcoming. 
[16] Calderon, C.A, Chong A., Loayza, N.V., 2002. Determinants of current account deficits in developing countries. Contributions to Macroeconomics 2 (1), 1-31.

[17] Chinn, M.D., 2005. Getting serious about the twin deficits. Council Special Report 10, Council of Foreign Relations.

[18] Chinn, M.D., 2011. Evidence on financial globalization and crises: global imbalances, forthcoming in Caprio, G. (Ed.), Encyclopedia of Financial Globalization, Elsevier.

[19] Chinn, M.D., Ito, H., 2008. A new measure of financial openness. Journal of Comparative Policy Analysis 10 (3), 309-322.

[20] Chinn, M.D., Prasad, E.S., 2003. Medium-term determinants of current accounts in industrial and developing countries: an empirical exploration. Journal of International Economics 59 (1), $47-76$.

[21] De Santis, R., Lührmann, M., 2008. On the determinants of net international portfolio flows: A global perspective. Journal of International Money and Finance 28, 890-901.

[22] Debelle, G., Faruque, H., 1996. What determines the current account? A cross-sectional and panel approach. IMF Working Paper No. 96/58. Washington, DC.

[23] Doisy, H., Herve, K., 2003. Les implications des deficits courants des PECO. Economie Internationale $95,59-88$.

[24] Eichengreen, B., 2006. Global imbalances: the new economy, the dark matter, the savvy investor, and the standard analysis. Journal of Policy Modelling 28, 645-652.

[25] European Central Bank, 2010. Prospects for real and financial imbalances and a global rebalancing. Monthly Bulletin, April, 91-100.

[26] Frankel, J., 2006. Could the twin deficits jeopardise US hegemony? Journal of Policy Modelling 28, 629-643.

[27] Galí, J., Lopez, J.D. and Valles, J., 2007. Understanding the effects of government spending on consumption. Journal of the European Economic Association 5 (1), 227-270.

[28] Glick, R., Rogoff, K., 1995. Global versus country-specific productivity shocks and the current account. Journal of Monetary Economics 35, 159-192.

[29] Gourinchas, P., 2008. Valuation effects and external adjustment: a review, in Cowan, K, Edwards, S., Valdes, R.O., Loayza, N., K. Schmid (Eds.), Current account and external financing, Central Bank of Chile 1(12), chapter 6, pp.195-236.

[30] Gourinchas, P., Rey, H., 2007. From world banker to world venture capitalist: US external adjustment and the exorbitant privilege, in: Clarida, R. (Ed.), G7 current account imbalances: sustainability and adjustment, The University of Chicago Press, pp. 11-55. 
[31] Gourinchas, P., Rey, H., Govillot, N., 2010. Exorbitant privilege and exorbitant duty. IMES Discussion Paper Series No. 10-E-20. Bank of Japan.

[32] Gruber, J., Kamin, S., 2005. Explaining the global pattern of current account imbalances. Board of Governors of the Federal Reserve System International Finance Discussion Papers No. 846.

[33] Habib, M.M., 2010. Excess returns on net foreign assets. The exorbitant privilege from a global perspective. ECB Working Paper No. 1158. Frankfurt.

[34] Hausmann, R., Sturzenegger, F., 2007. The missing dark matter in the wealth of nations and its implications for global imbalances. Economic Policy 22(51), 469-471.

[35] Herrmann, S., Jochem, A., 2005. Determinants of current account developments in the central and east European EU member states - consequences for the enlargement of the euro area. Discussion Paper Series 1: Economic Studies 32, Deutsche Bundesbank, Research Centre.

[36] Holtz-Eakin, D., 1988. Testing for individuals effects in autoregressive models. Journal of Econometrics 39, 297-307.

[37] IMF, 2006. Methodology for CGER exchange rate assessments. Research Department, International Monetary Fund, November 2006, available at: http://www.imf.org/external/np/pp/eng/2006/110806.pdf

[38] Krugman, P., 2007. Will there be a dollar crisis? Economic Policy, 22 (51), 435-467.

[39] Krugman, P., 2009. The return of depression economics and the crisis of 2008. W.W. Norton \& Company, New York.

[40] Laeven, L., Valencia, F., 2008. Systemic banking crises: a new database. IMF Working Paper No. 08/224. Washington, DC.

[41] Lane, P., Milesi-Ferretti, G., 2005a. A global perspective on external positions. CEPR. Discussion Papers No. 5234.

[42] Lane, P., Milesi-Ferretti, G., 2005b. Financial globalization and exchange rates. IMF Working Paper No. 05/3. Washington, DC.

[43] Lane, P., Milesi-Ferretti, G., 2007. The external wealth of nations mark II: revised and extended estimates of foreign assets and liabilities, 1970-2004. Journal of International Economics 73, November, 223-250.

[44] Ley, E., Steel, M.F.J., 2009. On the effect of prior assumptions in Bayesian model averaging with applications to growth regression. Journal of Applied Econometrics 24:4, 651-674

[45] Milbourne, R., Otto, G., 1992. Consumption smoothing and the current account. Australian Economic Papers 31 (59), 369-383. 
[46] Obstfeld, M., Rogoff, K., 1994. The intertemporal approach to the current account. NBER Working Paper No. 4893.

[47] Obstfeld, M., Rogoff, K. 2005. Global current account imbalances and exchange rate adjustments. Brooking Papers on Economic Activity 1, 67-123.

[48] Obstfeld, M., Rogoff, K., 2009. Global imbalances and the financial crisis: products of common causes. CEPR Discussion Papers No. 7606.

[49] Otto, G., 1992. Testing a present-value model of the current account evidence from U.S. and Canadian times series. Journal of International Money and Finance 11(5), 414-430.

[50] Otto, G., Voss, G.M., 1995. Consumption, external assets and the real interest rate. Journal of Macroeconomics 17 (3), 471-494.

[51] Pesaran, M.H., Smith, R., 1995. Estimating long-run relationships from dynamic heterogenous panels. Journal of Econometrics 68, 79-113.

[52] Rahman, J., 2008. Current account developments in new member states of the European Union: equilibrium, excess and EU-phoria. IMF Working Paper No. 08/92. Washington, DC.

[53] Reinhard, C., Rogoff, K., 2004. Serial default and the "paradox" of rich-to-poor capital flows. The American Economic Review 94 (2), 53-58.

[54] Sachs, J.D., 1981. The current account and macroeconomic adjustment in the 1970s. Brooking Papers on Economic Activity 1, 201-268.

[55] Sala-i-Martin, X., Doppelhofer G., Miller, R.I., 2004. Determinants of long-term growth: A Bayesian Averaging of Classical Estimates (BACE) Approach, The American Economic Review, $94(4), 813-35$.

[56] Sheffrin, S.M., Woo, W.T., 1990. Present value tests of an intertemporal model of the current account, Journal of International Economics 29, 237-253.

[57] Williamson, J., 2007. Are global imbalances a problem? Mimeo for the conference Currency and Competitiveness, Austrian National Bank, 19-20 November 2007.

[58] Zanghieri, P., 2004. Current accounts dynamics in new EU members: sustainability and policy issues. CEPII Working Papers 2004-07. 


\section{A Additional tables}

Table A.1: Data description

\begin{tabular}{|c|c|c|c|}
\hline Variable & $\begin{array}{c}\text { Deviation } \\
\text { from trading } \\
\text { partners }\end{array}$ & Source & Description \\
\hline Initial NFA & no & $\mathrm{L}-\mathrm{MF}$ & Net foreign assets as a share of GDP at the end of the previous year. \\
\hline Oil balance & no & WEO & Oil trade balance as a share of GDP. \\
\hline Investments & yes & WEO & Gross fixed investments as a share of GDP. \\
\hline Economic growth & yes & WEO & Real GDP growth. \\
\hline Fiscal balance & yes & WEO & Fiscal deficit as a share of GDP. \\
\hline Relative income & yes & WEO & Real GDP per capita in PPP terms, US $\$$. \\
\hline Population growth & yes & WEO & Annual growth of total population. \\
\hline Civil liberties & yes & FWS & Index between 1 (free) and 7 (not free). \\
\hline Openness & yes & WEO & Sum of exports and imports as a share of GDP. \\
\hline Financial integration & yes & $\mathrm{L}-\mathrm{MF}$ & Sum of external assets and liabilities as a share of GDP. \\
\hline Dependency ratio (old) & yes & WDI & Ratio of older people ( $>64$ years) to middle-age (15-64) cohort. \\
\hline Dependency ratio (young) & yes & WDI & Ratio of young people ( $<15$ years) to middle-age (15-64) cohort. \\
\hline Asian crisis dummy & yes & $\operatorname{IMF}(2006)$ & Equal to one from 1998 in all Asian countries. \\
\hline Current account & no & WEO & Current account as a share of GDP. \\
\hline Real effective exchange rate & no & WEO & Trade-weighted real eff. exch. rate based on PPP price indices. \\
\hline Chinn-Ito index & yes & C-I & Index, measuring financial openness. \\
\hline Financial sector reform & yes & A-D-T & Index, measuring financial liberalization. \\
\hline Terms of trade & no & WEO & Index, price of exports / price of imports, goods. \\
\hline \multirow[t]{2}{*}{ Deviation from UIP } & no & IFS, WEO & Short-term interest rate differential minus one-year lead \\
\hline & & & depreciation gap. \\
\hline Financial center dummy & yes & IMF (2006) & Equal to one for countries selected as financial centres. \\
\hline Capital gains & yes & L-MF, WEO & Equation 4 in Ca' Zorzi et al. (2011); Lane and Milesi-Ferretti (2005b) \\
\hline Banking crisis dummy & yes & $\mathrm{L}-\mathrm{V}$ & Equal to one in crisis year and the two following years. \\
\hline Country-specific trade weights & & DOTS & $\begin{array}{l}\text { Average bilateral trade flows during the period } 1996-2000 \text { for all coun- } \\
\text { tries in the database are used to construct the trade weights matrix. }\end{array}$ \\
\hline
\end{tabular}

Notes: L-MF is updated and extended version of dataset constructed by Lane and Milesi-Ferretti (2007), C-I stands for Chinn and Ito (2008), A-D-T for Abiad et al. (2008), L-V for Laeven and Valencia (2008); WEO is September 2008 version of IMF World Economic Outlook database, WDI is 2007 version of WB World Development Indicators database, FWS refers to annual Freedom in the World survey and DOTS is IMF Direction of Trade Statistics database. 
Table A.2: Robustness of BACE results to different samples.

\begin{tabular}{|c|c|c|c|c|c|c|}
\hline & \multicolumn{6}{|c|}{ Sample excludes: } \\
\hline & G7 & Lat. Am. & Em. Asia & Middle East & Africa & Euro Area \\
\hline \multirow[t]{2}{*}{ Initial NFA } & 0.031 & 0.026 & 0.034 & 0.036 & 0.031 & 0.032 \\
\hline & $(5.5)$ & $(2.7)$ & (6.6) & $(8.3)$ & $(5.2)$ & $(5.9)$ \\
\hline \multirow[t]{2}{*}{ Oil balance } & 0.142 & 0.140 & 0.171 & 0.279 & 0.162 & 0.142 \\
\hline & $(1.6)$ & $(1.6)$ & $(2.3)$ & $(3.1)$ & $(2.5)$ & $(1.7)$ \\
\hline \multirow[t]{2}{*}{ Investment } & -0.082 & 0.050 & -0.054 & -0.143 & -0.100 & -0.034 \\
\hline & $(-0.8)$ & $(0.7)$ & $(-0.6)$ & $(-1.7)$ & $(-0.8)$ & $(-0.4)$ \\
\hline \multirow[t]{2}{*}{ Economic growth } & 0.387 & 0.286 & 0.379 & 0.395 & 0.340 & 0.379 \\
\hline & $(1.3)$ & $(1.0)$ & $(1.1)$ & $(1.7)$ & $(1.0)$ & $(1.3)$ \\
\hline \multirow[t]{2}{*}{ Fiscal balance } & 0.198 & 0.234 & 0.148 & 0.312 & 0.286 & 0.188 \\
\hline & $(1.0)$ & $(1.3)$ & $(1.0)$ & $(2.8)$ & $(1.5)$ & $(1.0)$ \\
\hline \multirow[t]{2}{*}{ Relative income } & 0.038 & 0.034 & 0.021 & 0.015 & 0.017 & 0.030 \\
\hline & $(2.3)$ & $(1.8)$ & $(1.0)$ & $(0.8)$ & $(1.0)$ & $(1.6)$ \\
\hline \multirow[t]{2}{*}{ Population growth } & -1.402 & -1.128 & -0.944 & -1.610 & -0.728 & -1.135 \\
\hline & $(-1.7)$ & $(-1.2)$ & $(-1.3)$ & $(-2.2)$ & $(-0.9)$ & $(-1.2)$ \\
\hline \multirow[t]{2}{*}{ Civil liberties } & 0.007 & 0.007 & 0.008 & 0.003 & 0.003 & 0.007 \\
\hline & $(1.3)$ & $(1.4)$ & $(1.1)$ & $(0.8)$ & $(0.6)$ & $(1.3)$ \\
\hline \multirow[t]{2}{*}{ Openness } & 0.018 & 0.014 & 0.011 & 0.021 & 0.020 & 0.018 \\
\hline & $(1.2)$ & $(1.0)$ & $(0.8)$ & $(2.9)$ & $(2.2)$ & $(1.4)$ \\
\hline \multirow[t]{2}{*}{ Financial integration } & 0.004 & 0.005 & 0.003 & 0.004 & 0.004 & 0.003 \\
\hline & $(0.9)$ & $(1.0)$ & $(0.8)$ & $(0.8)$ & $(0.9)$ & $(0.7)$ \\
\hline \multirow[t]{2}{*}{ Dependency ratio (old) } & -0.321 & -0.264 & -0.116 & -0.172 & -0.061 & -0.266 \\
\hline & $(-1.9)$ & $(-1.6)$ & $(-0.7)$ & $(-1.0)$ & $(-0.4)$ & $(-1.4)$ \\
\hline \multirow[t]{2}{*}{ Dependency ratio (young) } & -0.052 & -0.064 & -0.051 & -0.042 & -0.061 & -0.061 \\
\hline & $(-1.0)$ & $(-1.4)$ & $(-1.3)$ & $(-0.8)$ & $(-1.5)$ & $(-1.3)$ \\
\hline \multirow[t]{2}{*}{ Relative income squared } & 0.010 & 0.008 & 0.006 & 0.004 & 0.007 & 0.008 \\
\hline & $(2.3)$ & $(1.8)$ & $(1.0)$ & $(1.1)$ & $(1.1)$ & $(1.6)$ \\
\hline \multirow[t]{2}{*}{ Asian crisis dummy } & 0.059 & 0.058 & -0.010 & 0.048 & 0.066 & 0.052 \\
\hline & $(1.8)$ & $(1.9)$ & $(-0.2)$ & $(1.3)$ & $(2.0)$ & $(1.4)$ \\
\hline No of countries & 70 & 66 & 64 & 68 & 58 & 64 \\
\hline No of observations & 1750 & 1650 & 1600 & 1700 & 1450 & 1600 \\
\hline Data shrinkage & 140 & 132 & 128 & 136 & 116 & 128 \\
\hline
\end{tabular}

Notes: Pooled ordinary least squares (OLS) estimation on the non-overlapping 12-year moving averages. Robust t-ratios are reported in parentheses. BACE results are for a prior of inclusions of 5 variables and the elasticities reported are conditional on the variable being included. 
Table A.3: Robustness of BACE results to different grouping / extra variables.

\begin{tabular}{|c|c|c|c|c|c|}
\hline & $\begin{array}{l}\text { High inc. } \\
\text { countries }\end{array}$ & $\begin{array}{l}\text { Low inc. } \\
\text { countries }\end{array}$ & $\begin{array}{c}\text { High NFA } \\
\text { countries }\end{array}$ & $\begin{array}{c}\text { Low NFA } \\
\text { countries }\end{array}$ & $\begin{array}{c}\text { Extended } \\
\text { set of regressors }\end{array}$ \\
\hline Initial NFA & $\begin{array}{c}0.030 \\
(1.6)\end{array}$ & $\begin{array}{c}0.029 \\
(7.6)\end{array}$ & $\begin{array}{c}0.017 \\
(0.8)\end{array}$ & $\begin{array}{c}0.031 \\
(10.4)\end{array}$ & $\begin{array}{l}0.025 \\
(0.95)\end{array}$ \\
\hline Oil balance & $\begin{array}{l}0.157 \\
(1.7)\end{array}$ & $\begin{array}{r}0.218 \\
(2.7)\end{array}$ & $\begin{array}{r}0.167 \\
(2.3)\end{array}$ & $\begin{array}{l}0.267 \\
(2.7)\end{array}$ & $\begin{array}{l}0.254 \\
(1.14)\end{array}$ \\
\hline Investment & $\begin{array}{l}0.224 \\
(1.0)\end{array}$ & $\begin{array}{c}-0.101 \\
(-1.1)\end{array}$ & $\begin{array}{l}0.095 \\
(0.8)\end{array}$ & $\begin{array}{l}-0.188 \\
(-1.9)\end{array}$ & $\begin{array}{l}-0.057 \\
(-0.55)\end{array}$ \\
\hline Economic growth & $\begin{array}{c}-0.034 \\
(-0.1)\end{array}$ & $\begin{array}{c}0.408 \\
(1.4)\end{array}$ & $\begin{array}{c}0.024 \\
(0.1)\end{array}$ & $\begin{array}{c}0.621 \\
(2.3)\end{array}$ & $\begin{array}{l}0.112 \\
(0.31)\end{array}$ \\
\hline Fiscal balance & $\begin{array}{c}0.130 \\
(0.7)\end{array}$ & $\begin{array}{c}0.093 \\
(0.6)\end{array}$ & $\begin{array}{l}0.166 \\
(1.0)\end{array}$ & $\begin{array}{c}0.305 \\
(1.3)\end{array}$ & $\begin{array}{l}0.110 \\
(0.95)\end{array}$ \\
\hline Relative income & $\begin{array}{c}0.035 \\
(2.6)\end{array}$ & $\begin{array}{r}0.007 \\
(0.6)\end{array}$ & $\begin{array}{l}0.029 \\
(1.2)\end{array}$ & $\begin{array}{r}0.011 \\
(1.0)\end{array}$ & $\begin{array}{l}0.006 \\
(0.43)\end{array}$ \\
\hline Population growth & $\begin{array}{l}-0.528 \\
(-0.7)\end{array}$ & $\begin{array}{c}-1.743 \\
(-2.4)\end{array}$ & $\begin{array}{l}-0.308 \\
(-0.4)\end{array}$ & $\begin{array}{c}-1.689 \\
(-1.4)\end{array}$ & $\begin{array}{l}-0.128 \\
(-0.20)\end{array}$ \\
\hline Civil liberties & $\begin{array}{c}0.010 \\
(1.1)\end{array}$ & $\begin{array}{c}0.005 \\
(0.9)\end{array}$ & $\begin{array}{c}0.007 \\
(1.2)\end{array}$ & $\begin{array}{c}0.004 \\
(0.7)\end{array}$ & $\begin{array}{l}0.003 \\
(0.85)\end{array}$ \\
\hline Openness & $\begin{array}{c}0.012 \\
(0.8)\end{array}$ & $\begin{array}{c}0.002 \\
(0.2)\end{array}$ & $\begin{array}{l}0.016 \\
(1.3)\end{array}$ & $\begin{array}{c}0.005 \\
(0.3)\end{array}$ & $\begin{array}{l}0.007 \\
(0.61)\end{array}$ \\
\hline Financial integration & $\begin{array}{c}0.008 \\
(2.2)\end{array}$ & $\begin{array}{c}0.000 \\
(0.0)\end{array}$ & $\begin{array}{c}0.006 \\
(1.3)\end{array}$ & $\begin{array}{c}0.001 \\
(0.1)\end{array}$ & $\begin{array}{l}0.000 \\
(0.12)\end{array}$ \\
\hline Dependency ratio (old) & $\begin{array}{c}0.036 \\
(0.2)\end{array}$ & $\begin{array}{c}-0.405 \\
(-3.1)\end{array}$ & $\begin{array}{c}-0.174 \\
(-1.0)\end{array}$ & $\begin{array}{c}-0.334 \\
(-2.5)\end{array}$ & $\begin{array}{l}-0.033 \\
(-0.34)\end{array}$ \\
\hline Dependency ratio (young) & $\begin{array}{c}-0.043 \\
(-0.6)\end{array}$ & $\begin{array}{c}-0.063 \\
(-1.0)\end{array}$ & $\begin{array}{l}-0.105 \\
(-2.8)\end{array}$ & $\begin{array}{c}-0.042 \\
(-0.7)\end{array}$ & $\begin{array}{l}-0.033 \\
(-0.52)\end{array}$ \\
\hline Relative income squared & $\begin{array}{c}0.011 \\
(0.7)\end{array}$ & $\begin{array}{c}-0.001 \\
(-0.2)\end{array}$ & $\begin{array}{c}0.009 \\
(1.3)\end{array}$ & $\begin{array}{c}-0.002 \\
(-0.6)\end{array}$ & $\begin{array}{l}-0.000 \\
(-0.08)\end{array}$ \\
\hline Asian crisis dummy & $\begin{array}{c}0.107 \\
(2.4)\end{array}$ & $\begin{array}{c}0.028 \\
(0.9)\end{array}$ & $\begin{array}{l}0.053 \\
(1.2)\end{array}$ & $\begin{array}{c}0.037 \\
(0.9)\end{array}$ & $\begin{array}{l}0.041 \\
(0.40)\end{array}$ \\
\hline Real effective exchange rate & & & & & $\begin{array}{l}0.007 \\
(0.13)\end{array}$ \\
\hline Chinn-Ito index & & & & & $\begin{array}{l}-0.000 \\
(-0.02)\end{array}$ \\
\hline Financial sector reform & & & & & $\begin{array}{l}0.001 \\
(0.12)\end{array}$ \\
\hline Terms of trade & & & & & $\begin{array}{l}0.001 \\
(0.03)\end{array}$ \\
\hline Deviation from UIP & & & & & $\begin{array}{l}-0.145 \\
(-0.91)\end{array}$ \\
\hline Capital gains & & & & & $\begin{array}{l}-0.012 \\
(-0.17)\end{array}$ \\
\hline Financial sector dummy & & & & & $\begin{array}{l}0.030 \\
(1.40)\end{array}$ \\
\hline Banking crisis dummy & & & & & $\begin{array}{l}-0.000 \\
(-0.04)\end{array}$ \\
\hline No of countries & 34 & 43 & 40 & 37 & 36 \\
\hline No of observations & 850 & 1075 & 1000 & 925 & 900 \\
\hline Data shrinkage & 68 & 86 & 80 & 74 & 72 \\
\hline
\end{tabular}

Notes: Pooled ordinary least squares (OLS) estimation on the non-overlapping 12-year moving averages. Robust t-ratios are reported in parentheses. BACE results are for a prior of inclusions of 5 variables and the elasticities reported are conditional on the variable being included. 


\section{B Implications of alternative model size priors}

Ley and Steel (2009) have shown that differences can arise, in the BACE approach, from different fixed hyper-parameters (model size priors). As the maximum model size is small relative to other examples of model averaging we are able to examine the robustness of our conclusions with respect to this hyper-parameter by considering all possible model sizes, i.e. from 1 to 13 variables, thus directly addressing the criticism of Ley and Steel (2009). An appealing way of presenting the results is Table B.1, which reports the posterior and prior probabilities of inclusion of variable for alternative hyper-parameters $k=1, . ., 13$. This table shows that NFA has a very high probability of inclusion in all cases. In addition, for three variables the posterior probability of inclusion is higher than the prior probability for all $k$, namely relative income, old-age dependency ratio and relative income squared.

Table B.1: Posterior and prior inclusion probabilities

\begin{tabular}{|c|c|c|c|c|c|c|c|c|c|c|c|c|c|}
\hline$k$ & 1 & 2 & 3 & 4 & 5 & 6 & 7 & 8 & 9 & 10 & 11 & 12 & 13 \\
\hline $\begin{array}{l}\text { Prior probabilities } \\
\text { (for each variable) }\end{array}$ & 0.07 & 0.14 & 0.21 & 0.29 & 0.36 & 0.43 & 0.50 & 0.57 & 0.64 & 0.71 & 0.79 & 0.86 & 0.93 \\
\hline Variable & \multicolumn{13}{|c|}{ Posterior probabilities } \\
\hline Initial NFA & 1.00 & 1.00 & 1.00 & 1.00 & 1.00 & 1.00 & 1.00 & 1.00 & 1.00 & 1.00 & 1.00 & 1.00 & 1.00 \\
\hline Oil balance & 0.90 & 0.85 & 0.81 & 0.77 & 0.74 & 0.72 & 0.70 & 0.70 & 0.70 & 0.70 & 0.71 & 0.73 & 0.76 \\
\hline Investments & 0.01 & 0.02 & 0.04 & 0.05 & 0.08 & 0.10 & 0.13 & 0.17 & 0.21 & 0.27 & 0.33 & 0.42 & 0.53 \\
\hline Economic growth & 0.23 & 0.30 & 0.34 & 0.38 & 0.40 & 0.41 & 0.43 & 0.44 & 0.46 & 0.49 & 0.53 & 0.58 & 0.65 \\
\hline Fiscal balance & 0.23 & 0.27 & 0.29 & 0.29 & 0.28 & 0.27 & 0.25 & 0.24 & 0.24 & 0.24 & 0.25 & 0.28 & 0.33 \\
\hline Relative income & 0.16 & 0.25 & 0.36 & 0.46 & 0.56 & 0.65 & 0.73 & 0.80 & 0.85 & 0.90 & 0.93 & 0.96 & 0.98 \\
\hline Population growth & 0.23 & 0.26 & 0.31 & 0.37 & 0.44 & 0.51 & 0.59 & 0.66 & 0.72 & 0.78 & 0.84 & 0.88 & 0.92 \\
\hline Civil liberties & 0.09 & 0.15 & 0.22 & 0.28 & 0.34 & 0.39 & 0.43 & 0.48 & 0.52 & 0.56 & 0.61 & 0.66 & 0.73 \\
\hline Openness & 0.54 & 0.53 & 0.49 & 0.45 & 0.41 & 0.38 & 0.35 & 0.34 & 0.33 & 0.32 & 0.33 & 0.35 & 0.38 \\
\hline Financial int. & 0.04 & 0.06 & 0.08 & 0.11 & 0.14 & 0.17 & 0.20 & 0.24 & 0.28 & 0.32 & 0.37 & 0.43 & 0.50 \\
\hline Dependency ratio (old) & 0.08 & 0.16 & 0.25 & 0.34 & 0.44 & 0.53 & 0.62 & 0.70 & 0.76 & 0.82 & 0.87 & 0.91 & 0.95 \\
\hline Dependency ratio (young) & 0.53 & 0.50 & 0.46 & 0.41 & 0.36 & 0.32 & 0.28 & 0.25 & 0.23 & 0.21 & 0.21 & 0.22 & 0.24 \\
\hline Relative income squared & 0.11 & 0.22 & 0.34 & 0.45 & 0.56 & 0.65 & 0.73 & 0.80 & 0.86 & 0.90 & 0.94 & 0.96 & 0.98 \\
\hline Asian crisis dummy & 0.15 & 0.24 & 0.32 & 0.39 & 0.45 & 0.51 & 0.56 & 0.61 & 0.66 & 0.70 & 0.74 & 0.79 & 0.83 \\
\hline
\end{tabular}

Notes: Posterior probabilities larger then the corresponding prior probabilities are highlighted by bold font. 